\title{
An Experimental Host Range for Triticum mosaic virus
}

Dallas L. Seifers, Professor, and T. J. Martin, Professor, Kansas State University, Agricultural Research CenterHays, Hays 67601-9228; and J. P. Fellers, United States Department of Agriculture-Agricultural Research Service HWWGRU, Department of Plant Pathology, Manhattan, KS 66506

\begin{abstract}
Seifers, D. L., Martin, T. J., and Fellers, J. P. 2010. An experimental host range for Triticum mosaic virus. Plant Dis. 94:1125-1131.

Triticum mosaic virus (TriMV) is a newly discovered virus isolated from wheat (Triticum aestivum). This study was conducted to determine an experimental host range for TriMV and identify species that could serve as differential hosts for isolating TriMV from Wheat streak mosaic virus (WSMV). Plants tested were mechanically inoculated with the 06-123 isolate of TriMV or the Sidney 81 isolate of WSMV. Some plants were analyzed by enzyme-linked immunosorbent assay (ELISA) using antibodies of TriMV and WSMV. Plants infected with TriMV always produced mosaic symptoms and only extracts of symptomatic plants reacted with antibodies of TriMV. Maize is not a host for TriMV but barley, oat, rye, and triticale are hosts of TriMV. Certain barley and triticale accessions are hosts for TriMV but not WSMV. These plants can be used in combination with maize to separate WSMV and TriMV in plants infected by both viruses. We also showed that 8 wild grass species were susceptible to TriMV and 25 were not. All of the grasses susceptible to infection with TriMV have been reported as susceptible to infection with WSMV. Because of their growth habits, these plant species would be less desirable for use as differential hosts than maize, barley, and triticale.
\end{abstract}

Triticum mosaic virus (TriMV) was first identified infecting wheat (Triticum aestivum L.) in Kansas in 2006 (16). TriMV has since been identified from infected wheat in: Colorado, Nebraska, Oklahoma, South Dakota, Texas, and Wyoming (2). The virus is mechanically transmissible, and associated with a $35-\mathrm{kDa}$ coat protein when analyzed by sodium dodecyl sulfate polyacrylamide gel electrophoresis (SDSPAGE). Antiserum raised to the coat protein preferentially reacted only to TriMV in an enzyme-linked immunosorbent assay (ELISA) and a Western blot assay. Symptomatic plants were shown to be associated with flexuous rods when analyzed by electron microscopy.

The sequence of the coat protein of TriMV was determined by time-of-flight mass spectroscopy and from DNA sequenced of cloned, reverse-transcribed viral RNA. TriMV was found to be distantly related to Sugarcane streak mosaic virus (16). The complete nucleotide sequences of the Kansas 06-123 isolate (5) and a Nebraska isolate (25) of TriMV have been determined.

Corresponding author: D. L. Seifers

E-mail: dseifers@ksu.edu

Contribution no. 10-252-J from the Kansas Agricultural Experiment Station. Research was supported in part by a grant from the Kansas Wheat Commission.

Accepted for publication 19 May 2010.

doi:10.1094/PDIS-94-9-1125

(C) 2010 The American Phytopathological Society
Wheat curl mites (WCM) (Aceria tosichella Keifer) were observed on plants originally infected with TriMV (16). Subsequent studies using WCM obtained from Ellis County, KS demonstrated that these WCM could transmit TriMV both singly and in combination with Wheat streak mosaic virus (WSMV; 15). The WCM also transmits WSMV (22) and the High Plains virus (HPV) (12).

Previously, only wheat and barley have been confirmed as hosts of TriMV (16); therefore, we tested a greater range of plants for susceptibility to mechanical infection with TriMV to determine an experimental host range for this virus and identify plant species that might serve as differential hosts for TriMV and WSMV.

\section{MATERIALS AND METHODS}

Virus isolates. The 06-123 isolate of TriMV was isolated from KS06HW79 wheat in 2006 at the Kansas Agricultural Research Center-Hays (KSU-ARCH) at Hays, KS (16). The Sidney 81 isolate of WSMV was collected at Sidney, NE in 1981 and was obtained from W. G. Langenberg (17). Systemically infected wheat was used as the inoculum source for propagation of these isolates using the leaf-rub technique described previously (14). Following inoculation, the plants were held in a greenhouse under natural lighting.

Sources of antiserum. Anti-TriMV serum was used as a whole serum at a $1: 4,000$ ( $\mathrm{vol} / \mathrm{vol})$ dilution and was prepared as described previously (16), and antiserum prepared to WSMV was used at a 1:1,000 (vol/vol) dilution (10). Working dilutions were made from stocks adjusted to protein at $1 \mathrm{mg} / \mathrm{ml}$.

Indirect ELISA. The ELISA procedure was conducted as described previously (16). Antiserum concentrations were used as described above. The goat anti-rabbit antibody/alkaline phosphatase conjugate was used at a dilution of 1:3,000 vol/vol (Southern Biotechnology Associates, Birmingham, AL). Absorbance was measured at $405 \mathrm{~nm}$ using a Titertek Multiscan plate reader (Flow Laboratories, Inc., McLean, VA). Absorbance values were arbitrarily considered positive if they were twice those of the equivalent mock-inoculated control.

Host range. The sources of the seed for these plant species tested are provided in Table 1 . The maize, barley, oat, rye, pearl millet, sorghum, and triticale seed were planted into metal $(21-$ by $31-\mathrm{cm})$ flats filled with a Harney clay loam soil (fine montmorillonitic, mesic type Argiustoll) having 22 rows per flat so that two sets of each seed source were planted. However, one set of each seed source of pearl millet and sorghum were planted. Each species was planted in separate experiments. At the two-leaf stage, one set of plants was mechanically inoculated with a 1:10 (wt/vol) extract of TriMV-infected wheat and the other set with an extract from wheat infected with WSMV. The inoculum for each virus was prepared from Tomahawk wheat inoculated 14 to 21 days previously with either TriMV or WSMV. Sorghum and pearl millet plants were inoculated only with TriMV. Following inoculation, the plants were held in a greenhouse under natural lighting. After 21 days in the greenhouse, the plants were rated for symptoms and, in the first experiment, either the third or fourth leaf was harvested and analyzed in ELISA using antibodies prepared to either TriMV or WSMV. Unless otherwise stated, the experiments were repeated three times.

Wild grasses. Seed sources of wild grasses used are listed in Table 1. Seed of these grasses were planted into soil-filled "plant cells" (Stuewe \& Sons, Corvallis, OR) and inoculated at the two- to threeleaf stage with TriMV. Following inoculation, the plants were held in a greenhouse under natural lighting. After 21 days in the greenhouse, the plants were rated for symptoms. A plant species was tested in two experiments if it was infected with TriMV; a species symptomless following 
Table 1. Names and seed sources of plants used in host range experiments

\begin{tabular}{|c|c|c|}
\hline Species & Common name & Source $^{a}$ \\
\hline Aegilops cylindrica Host & Jointed goatgrass & 3 \\
\hline Andropogon gerardi Vitman & Big bluestem & 3 \\
\hline Avena fatua $\mathrm{L}$. & Wild oats & 2 \\
\hline A. sativa $\mathrm{L}$. & 'Armor' & 13 \\
\hline A. sativa $\mathrm{L}$. & 'Brawn' & 13 \\
\hline A. sativa $\mathrm{L}$. & 'Chairman' & 13 \\
\hline A. sativa $\mathrm{L}$. & 'Lodi' & 13 \\
\hline A. sativa $\mathrm{L}$. & 'Rio Grande' & 13 \\
\hline Bouteloua curtipendula (Michx.) Torr. & Sideoats grama & 3 \\
\hline B. gracilis (Willd. ex Kunth) Lag. ex Griffiths & Blue grama 'El Reno' & 3 \\
\hline Bromus arvensis $\mathrm{L} .=($ Bromus japonicas $)$ & Field brome & 1 \\
\hline B. inermis Leyss. & Smooth brome & 3 \\
\hline B. secalinus $\mathrm{L}$. & Rye brome & 1 \\
\hline B. tectorum L. & Cheatgrass & 1 \\
\hline Cenchrus longispinus (Hack.) Fernald & Mat sandbur & 1 \\
\hline Chloris gayana Kunth & Rhodes grass & 8 \\
\hline C. ventricosa $\mathrm{R} ., \mathrm{Br}$. & Australian Windmill grass & 8 \\
\hline Dactylis glomerata $\mathrm{L}$. & Orchardgrass & 2 \\
\hline Digitaria sanguinalis (L.) Scop. & Hairy crabgrass & 1 \\
\hline Echinochloa crus-galli (L.) P. Beauv. & Barnyard grass & 1 \\
\hline Elymus repens $(\mathrm{L}$.$) Gould =($ Agropyron repens $)$ & Quackgrass & 2 \\
\hline Eragrostis cilianensis (All.) Link ex Vign. & Stinkgrass & 1 \\
\hline Eriochloa acuminata (J. Presl) Kunth & Tapertip cupgrass & 1 \\
\hline E. contracta Hitchc. & Prairie cupgrass & 1 \\
\hline Hordeum vulgare $\mathrm{L}$. & 'Baronesse' & 7 \\
\hline H. vulgare $\mathrm{L}$. & BZ-489-74 & 14 \\
\hline H. vulgare $\mathrm{L}$. & 'Black hulless' & 14 \\
\hline H. vulgare $\mathrm{L}$. & 'Gallatin' & 7 \\
\hline H. vulgare $\mathrm{L}$. & 'Horseford Hay' & 7 \\
\hline H. vulgare $\mathrm{L}$. & 'Westford' & 7 \\
\hline H. vulgare $\mathrm{L}$. & 'Lewis' & 7 \\
\hline H. vulgare $\mathrm{L}$. & 'Summit' & 7 \\
\hline H. vulgare $\mathrm{L}$. & 'Westbred medallion' & 7 \\
\hline H. vulgare $\mathrm{L}$. & 'Westford' & 7 \\
\hline Lolium perenne L. subsp. multiflorum (Lam.) Husnot $=($ Lolium multiflorum $)$ & Italian ryegrass & 2 \\
\hline L. perenne L. subsp. perenne & Perennial ryegrass & 2 \\
\hline Panicum capillare $\mathrm{L}$. & Witchgrass & 1 \\
\hline P. dichotomiflorum Michx. & Fall panicgrass & 2 \\
\hline P. maximum Jacq. R. Webster & Guineagrass & 2 \\
\hline P. miliaceum L. & Broomcorn millet & 1 \\
\hline$P$. virgatum $\mathrm{L}$. & Switchgrass & 2 \\
\hline Pascopyrum smithii (Rydb.) A. Love $=($ Agropyron smithii $)$ & Western wheatgrass & 3 \\
\hline Pennisetum glaucum (L.) R. Br. & Pearl millet (94-6667) & 1 \\
\hline Poa pratensis L. & Kentucky bluegrass & 3 \\
\hline Schizachyrium scoparium $($ Michx.) Nash $=($ Andropogon scoparius $)$ & Little bluestem & 3 \\
\hline Secale cereale $\mathrm{L}$. & 'Bonel', & 1 \\
\hline S. cereale $\mathrm{L}$. & 'Mayton' & 6 \\
\hline Setaria pumila (Poir.) Roem. \& Schult subsp. pumila $=($ Setaria glauca $)$ & Yellow foxtail & 1 \\
\hline S. viridis (L.) P. Beauv. & Green bristlegrass & 1 \\
\hline Sorghum bicolor (L.) Moench. & IS1056 & 1 \\
\hline S. bicolor (L.) Moench. & KS56A & 1 \\
\hline S. bicolor (L.) Moench. & PI550610 & 1 \\
\hline S. bicolor (L.) Moench. & TX626 & 1 \\
\hline S. bicolor (L.) Moench. & TX 632 & 1 \\
\hline S. bicolor (L.) Moench. & TX 636 & 1 \\
\hline S. bicolor (L.) Moench. & TX 2567 & 1 \\
\hline S. halapense (L.) Pers. & Johnsongrass & 2 \\
\hline Thinopyrum intermedium $($ Host $)$ Barkw \& D.R. Dewey subsp. intermedium $)=($ Agropyron intermedium $)$ & Intermediate wheatgrass & 3 \\
\hline T. ponticum (Podp.) Z.-W. Liu \& R.-C Wang = (A. elongatum $)$ & Tall wheatgrass & 3 \\
\hline Tripsacum dactyloides (L.) L. & Eastern gamagrass & 3 \\
\hline Triticale $(\times$ Triticosecale rimpani Wittmack) & 'Arcia' & 9 \\
\hline Triticale & FL010-G7 & 9 \\
\hline Triticale & FL98122-H3 & 9 \\
\hline Triticale & FL98178-H4 & 9 \\
\hline Triticale & NCPT01-1433 & 9 \\
\hline Triticale & NCPT04-2151 & 9 \\
\hline Triticale & NCT021619 & 9 \\
\hline
\end{tabular}

(continued on next page)

a Seed source: 1 = Kansas State University Agricultural Experiment Station-Hays; 2 = Valley Seed Service, Fresno, CA 93791; 3 = Sharp Bros. Seeds, Healy, KS 67850; 4 = Ohio Agricultural Research and Development Center, Wooster 44691; 5 = Dr. David Baltensperger, University of Nebraska, Scottsbluff 69361; 6 = National Small Grains Collection, United States Department of Agriculture-Agricultural Research Service, Aberdeen, ID 83210; 7 = Townsend Seeds, Inc., Townsend, MT 59644; 8 = Regional Plant Introduction Station, Griffin, GA 30223-1797; $9=$ Triticale seed obtained from P. S. Baenziger, University of Nebraska-Lincoln, Lincoln 68583; $10=$ Commercial cultivar; $11=$ North Central Regional Plant Station, Ames, IA 50011; $12=$ Robson Seed Farms, Hall, NY 14463; 13 = Dr. Kraig Roozeboom, Manhattan, KS 66506; and 14 = Western Plant Breeders, Bozeman, MT 59715. 
Table 1. (continued from preceding page)

\begin{tabular}{|c|c|c|}
\hline Species & Common name & Source $^{\mathrm{a}}$ \\
\hline Triticale & NCT99-821 & 9 \\
\hline Triticale & NE03T407 & 9 \\
\hline Triticale & NE03T449 & 9 \\
\hline Triticale & NT01435 & 9 \\
\hline Triticale & NT01451 & 9 \\
\hline Triticale & NT02458 & 9 \\
\hline Triticale & 'Sunland' & 9 \\
\hline Triticale & 'Trical 342' & 9 \\
\hline Triticum aestivum $\mathrm{L}$. & Tomahawk wheat & 1 \\
\hline Zea mays L. & H84Ht (PI587128) & 4 \\
\hline Z. mays L. & B73Ht (PI550473) & 11 \\
\hline Z. mays L. & 'Candy Corner' & 10 \\
\hline Z. mays L. & 'Chubby Checkers' & 10 \\
\hline Z. mays L. & ‘Country Gentleman’ (Ames 14238) & 11 \\
\hline Z. mays L. & 'Early \& Often' & 10 \\
\hline Z. mays L. & 'Early Golden Bantam' & 10 \\
\hline Z. mays L. & 'Early Sunglow' & 10 \\
\hline Z. mays L. & 'Falconer' (PI213781) & 11 \\
\hline Z. mays L. & 'Midland' (PI221877) & 11 \\
\hline Z. mays L. & N28Ht (Ames 27138) & 11 \\
\hline Z. mays L. & Pa405 (Ames 22752) & 11 \\
\hline Z. mays L. & 'Peaches \& Cream' & 10 \\
\hline Z. mays L. & 'Seneca Chief' & 12 \\
\hline Z. mays L. & 'Silver Choice' & 10 \\
\hline Z. mays L. & 'Silver Queen' & 10 \\
\hline Z. mays L. & 'Sugar Dots' & 10 \\
\hline Z. mays L. & 'Sweet Sunshine' & 10 \\
\hline
\end{tabular}

Table 2. Numbers of maize and wheat (Tomahawk) plants with mosaic symptoms 21 days following mechanical inoculation with Triticum mosaic virus (TriMV) or Wheat streak mosaic virus (WSMV) and enzyme-linked immunosorbent assay (ELISA) values from symptomatic (S) or nonsymptomatic (NS) plants $^{\mathrm{a}}$

\begin{tabular}{|c|c|c|c|c|c|c|}
\hline \multirow[b]{3}{*}{ Plant sample } & \multirow[b]{3}{*}{ TriMVc } & \multirow[b]{3}{*}{ WSMVc $^{c}$} & \multicolumn{4}{|c|}{ Antiserum (absorbance value) ${ }^{b}$} \\
\hline & & & \multicolumn{2}{|c|}{ TriMV } & \multicolumn{2}{|c|}{ WSMV } \\
\hline & & & $\mathbf{S}$ & NS & $\mathbf{S}$ & NS \\
\hline Country Gentleman & $0 / 20$ & $4 / 19$ & NA & 0.006 & 0.269 & 0.018 \\
\hline $\mathrm{Pa} 405$ & $0 / 22$ & $0 / 24$ & NA & 0.006 & NA & 0.026 \\
\hline $\mathrm{N} 28 \mathrm{Ht}$ & $0 / 19$ & $15 / 19$ & NA & 0.005 & 0.286 & 0.014 \\
\hline Falconer & $0 / 23$ & $7 / 22$ & NA & 0.006 & 0.286 & 0.020 \\
\hline Midland & $0 / 21$ & $10 / 21$ & NA & 0.006 & 0.323 & 0.030 \\
\hline B73Ht & $0 / 23$ & $0 / 22$ & NA & 0.006 & NA & 0.027 \\
\hline $\mathrm{H} 84 \mathrm{Ht}$ & $0 / 20$ & $0 / 20$ & NA & 0.006 & NA & 0.039 \\
\hline Tomahawk & $30 / 30$ & $29 / 29$ & 0.357 & NA & 0.394 & NA \\
\hline WSMV virus control & NA & NA & 0.004 & NA & 0.187 & NA \\
\hline TriMV virus control & NA & NA & 0.181 & NA & 0.013 & NA \\
\hline Wheat healthy control & NA & NA & NA & 0.015 & NA & 0.010 \\
\hline Maize healthy control & NA & NA & NA & 0.018 & NA & 0.021 \\
\hline
\end{tabular}

inoculation with TriMV was tested in three experiments. In a given test, a species with only symptomless plants had the leaves bulked within a row and these leaves were then tested in ELISA using antibodies prepared to TriMV. A single symptomatic plant (if present) from a given line was also randomly sampled as an internal control along with the Tomahawk plants inoculated with TriMV. The temperature ranged from 18 to $30^{\circ} \mathrm{C}$ during these experiments. In Table 1 , the scientific names of several grasses have changed; however, the older names have been provided as well, to provide conti- nuity with the host range information with other viruses (13).

\section{RESULTS}

The first set of maize hybrids and lines initially tested by inoculation with TriMV were not infected (Table 2). The 'Tomahawk' wheat susceptible control plants were infected, indicating that the TriMV inoculum was infective. When the second set of plants of these lines were inoculated with WSMV, 'Country Gentleman', $\mathrm{N} 28 \mathrm{Ht}$, 'Falconer', and 'Midland' had systemically infected plants with mosaic symptoms similar to the Tomahawk wheat control plants. All symptomatic plants reacted only to the antiserum made to the respective inoculation virus. Symptomless plants inoculated with TriMV or WSMV did not react to antibodies prepared to these viruses in ELISA. We analyzed only the first experiment of this set of plants by ELISA because only extracts from symptomatic plants reacted with a respective antibody, indicating that none of the plants represented symptomless infections.

Additional maize hybrids were tested for infection with TriMV but none were susceptible (Table 3). In contrast, the maize hybrids 'Chubby Checkers', 'Early 
Golden Bantam', 'Early \& Often', 'Early Sunglow', 'Sugar Dots', 'Silver Queen', Country Gentleman, and 'Seneca Chief' had plants symptomatic for WSMV in the three experiments. These plants were not analyzed by ELISA because we showed that only symptomatic plants reacted to antibodies of TriMV and WSMV in the first set of experiments (Table 2).

Analysis of nine barley sources inoculated with TriMV showed that all had plants that were susceptible (mosaic symptoms) to infection (Table 4). In contrast, only the 'Black Hulless', 'Lewis', 'Sum-

Table 3. Number of plants with mosaic symptoms after mechanical inoculation with either Triticum mosaic virus (TriMV) or Wheat streak mosaic virus (WSMV)

\begin{tabular}{lcc}
\hline Plant source $^{\mathbf{a}}$ & TriMV $^{\mathbf{b}}$ & WSMV $^{\mathbf{b}}$ \\
\hline B73 & $0 / 19$ & $0 / 19$ \\
Candy Corner & $0 / 16$ & $0 / 19$ \\
Chubby Checkers & $0 / 16$ & $1 / 18$ \\
Country Gentleman & $0 / 17$ & $2 / 17$ \\
Early \& Often & $0 / 22$ & $1 / 23$ \\
Early Golden Bantam & $0 / 8$ & $3 / 14$ \\
Early Sunglow & $0 / 22$ & $4 / 21$ \\
Peaches \& Cream & $0 / 23$ & $0 / 24$ \\
Seneca Chief & $0 / 23$ & $1 / 23$ \\
Silver Choice & $0 / 10$ & $0 / 12$ \\
Silver Queen & $0 / 22$ & $5 / 22$ \\
Sugar Dots & $0 / 24$ & $2 / 25$ \\
Sweet Sunshine & $0 / 23$ & $0 / 23$ \\
Tomahawk & $22 / 22$ & $27 / 27$ \\
\hline
\end{tabular}

a Tomahawk was a wheat cultivar and all other entries were maize hybrids. Maize hybrids were obtained from a commercial source.

b Inoculation viruses were the 06-123 isolate of TriMV and the Sidney 81 isolate of WSMV. The numerator represents the number of symptomatic plants and the denominator the total number of plants inoculated. The temperature ranged from 17 to $26^{\circ} \mathrm{C}$ during the experiments. mit', 'Westbred Medallion', and 'Westford' barley sources had plants that were susceptible to infection with WSMV. Symptomless barley plants inoculated with TriMV or WSMV did not react to antibodies prepared to WSMV or TriMV.

The oat cultivars inoculated with TriMV or WSMV all had plants that were susceptible (mosaic symptoms) to infection with both viruses (Table 5). 'Lodi' and 'Rio Grande' had the least number of plants infected with TriMV and 'Brawn' the least number infected with WSMV. ELISA values for TriMV in oat cultivars were lower than those for WSMV in oats.

All rye cultivars analyzed under TriMV or WSMV pressure were susceptible to infection with both viruses (Table 6). Both cultivars had high numbers of plants infected with TriMV but low numbers of plants infected with WSMV. ELISA values were lower for all plants infected with TriMV than for WSMV but this was also observed for the TriMV control compared with the WSMV control.

Fifteen triticale sources were tested for susceptibility to infection with either TriMV or WSMV (Table 7). All lines had plants that were susceptible (mosaic symptoms) to infection with TriMV. Testing with WSMV showed that only FL98178H4, NCPT01-1433, and 'Arcia' were resistant to infection with WSMV.

Wild grasses, pearl millet, and sorghum lines were tested for susceptibility to infection with TriMV (Table 8). Species susceptible to infection with TriMV were jointed goatgrass, wild oats, rye brome, cheatgrass (downy brome), field brome, prairie cupgrass, tapertip cupgrass, and green bristlegrass.

Many plant species tested were not infected by TriMV in our studies (Table 8): barnyardgrass, mat sandbur, orchardgrass, hairy crabgrass, stinkgrass, perennial ryegrass, fall panicgrass, broomcorn millet, switchgrass, Kentucky bluegrass, blue grama, big bluestem, little bluestem, eastern gamagrass, johnsongrass, quackgrass, sideoats grama, intermediate wheatgrass, pearl millet, tall wheatgrass, western wheatgrass, rhodes grass, Australian windmill grass, smooth brome, yellow foxtail, and the sorghum lines IS1056, KS56A, PI550610, TX626, TX632, TX636, and TX2567. Only extracts from symptomatic plants reacted with TriMV antibodies when analyzed by ELISA, and only the symptomatic Tomahawk wheat control plants infected with TriMV reacted to antibodies of TriMV (data not shown).

\section{DISCUSSION}

We observed that all maize lines or hybrids were not infected with TriMV following mechanical inoculation (Tables 2 and 3). However, in our first maize experiments, we found that Country Gentleman, N28Ht, Falconer, and Midland maize were susceptible to infection with WSMV and the other maize lines were not susceptible (Table 2). The susceptibility of N28Ht to infection with WSMV (9) and Falconer and Midland (19) are in keeping with previous results. The Pa405 (8), B73 (8), and H84 (9) lines have been reported as being immune to infection with WSMV. However, we infected 4 of 19 Country Gentleman plants with WSMV, in contrast to previous work that reported this cultivar as immune (21). The four infected Country Gentleman plants occurred in the first experiment only. However, in our second set of maize experiments, we found that Country Gentleman had 2 of 17 plants infected with WSMV, each plant in a dif-

Table 4. Numbers of barley plants with mosaic symptoms 21 days following mechanical inoculation with Triticum mosaic virus (TriMV) or Wheat streak mosaic virus (WSMV) and enzyme-linked immunosorbent assay (ELISA) values from symptomatic (S) or nonsymptomatic (NS) plants ${ }^{\mathrm{a}}$

\begin{tabular}{|c|c|c|c|c|c|c|}
\hline \multirow[b]{3}{*}{ Plant source ${ }^{\mathrm{c}}$} & \multirow[b]{3}{*}{ TriMV $^{d}$} & \multirow[b]{3}{*}{ WSMV $^{\mathbf{d}}$} & \multicolumn{4}{|c|}{ Antiserum (absorbance value) ${ }^{\mathbf{b}}$} \\
\hline & & & \multicolumn{2}{|c|}{ TriMV } & \multicolumn{2}{|c|}{ WSMV } \\
\hline & & & $\mathbf{S}$ & NS & $\mathbf{S}$ & NS \\
\hline Baronesse & $8 / 21$ & $0 / 17$ & 0.333 & 0.009 & NA & 0.018 \\
\hline Black Hulless & $12 / 14$ & $10 / 12$ & 0.410 & 0.011 & 0.318 & 0.014 \\
\hline BZ-489-74 & $13 / 18$ & $0 / 10$ & 0.385 & 0.003 & NA & 0.010 \\
\hline Gallatin & $21 / 21$ & $0 / 16$ & 0.435 & NA & NA & 0.002 \\
\hline Horsford Hay & $16 / 17$ & $0 / 17$ & 0.312 & 0.031 & NA & 0.019 \\
\hline Lewis & $16 / 16$ & $6 / 16$ & 0.387 & NA & 0.212 & 0.017 \\
\hline Summit & $16 / 20$ & $1 / 20$ & 0.412 & 0.007 & 0.081 & 0.021 \\
\hline Westbred Medallion & $20 / 20$ & $18 / 20$ & 0.366 & NA & 0.340 & 0.015 \\
\hline Westford & $20 / 20$ & $18 / 20$ & 0.336 & NA & 0.218 & 0.014 \\
\hline Tomahawk wheat & $20 / 20$ & $15 / 15$ & 0.337 & NA & 0.225 & NA \\
\hline TriMV ELISA control (EC) & NA & NA & 0.283 & NA & 0.025 & NA \\
\hline WSMV EC & NA & NA & 0.010 & NA & 0.176 & NA \\
\hline Healthy barley EC & NA & NA & NA & 0.009 & NA & 0.015 \\
\hline
\end{tabular}

${ }^{a}$ Inoculation viruses were the 06-123 isolate of TriMV and the Sidney 81 isolate of WSMV.

${ }^{b}$ Mean absorbance values are from one experiment. Means were determined from the numbers of symptomatic or nonsymptomatic plants in a treatment (e.g., the 0.333 value for Baronesse barley was the mean of the ELISA values of the eight symptomatic plants). Because only symptomatic plant extracts reacted with antibodies to the homologous virus with which the plants were inoculated and not symptomless plants, the plants in the other experiment were not analyzed (NA) by ELISA.

${ }^{\mathrm{c}}$ Tomahawk was a wheat cultivar and all other entries were barley.

${ }^{\mathrm{d}}$ The numerator represents the number of systemically infected plants with mosaic symptoms and the denominator the total number of plants inoculated. Plants were from two experiments. The temperature ranged from 16 to $26^{\circ} \mathrm{C}$ during the experiments. 
ferent experiment. This difference may result from off-types that may have been in our seed source. It is also a possibility that the seed of cv. Country Gentleman were genetically uniform but the plants were not easily infected by mechanical inoculation. We have observed this with wheat cv. Ike that is susceptible to infection by WSMV in the field but is difficult to infect by mechanical inoculation (D. L. Seifers, unpublished). No information is available concerning the reaction of the Chubby Checkers, Early Golden Bantam, Early \& Often, Early Sunglow, Sugar Dots, and Silver Queen to inoculation with WSMV. However, Seneca Chief has been reported to be susceptible to infection with WSMV (9). These maize lines provide a means to obtain WSMV free of TriMV from a source infected by both viruses. In our analyses (with one TriMV isolate), we could not mechanically infect maize lines or hybrids, indicating that TriMV may not pose a threat to maize production.

All barley accessions were susceptible to infection with TriMV (Table 4). We reported in an earlier study (16) natural infection of barley by TriMV, in which eight barley lines had a few symptomatic plants, four lines each had a single infected plant, two lines had a single plant infected with WSMV only, and two lines had a single plant infected with both TriMV and WSMV. Barley is listed as a host for WSMV (20); however, we observed that not all barley accessions ('Baronesse', 'Gallatin', 'Horsford Hay', and BZ-48974) tested were susceptible to infection with WSMV following mechanical inoculation. Thus, these barley accessions could serve as a set of differential hosts for TriMV and WSMV. Using Gallatin barley and $\mathrm{N} 28 \mathrm{Ht}$ maize, we were able to isolate TriMV free of WSMV, and then used that isolate in studies identifying that the WCM was the vector of TriMV (15). Other work has shown that not all barley sources are susceptible to infection with WSMV (1). In that study, cv. Rodeo was immune to both the PV 57 and PV 106 isolates of WSMV but six other cultivars were susceptible to both virus isolates.

The results of our experiments with oat (Table 5) and rye (Table 6) accessions showed that they all had plants that were susceptible to infection with either TriMV or WSMV. Oat and rye have been shown previously to be a host for WSMV (20).

The 15 triticale lines or cultivars tested all had plants that were susceptible to infection with TriMV (Table 7). Interestingly, we observed that, when inoculated with WSMV, only the lines FL98178-H4 and NCPT01-1433 and cv. Arcia had plants that were not infected. As with barley, triticale can provide a differential host for TriMV and WSMV. Previous work has shown that triticale lines are susceptible to infection with WSMV (6). In that study, an unidentified isolate of WSMV was used to mechanically inoculate 33 triticale sources; 3 were considered immune and the remainder had levels of infection ranging from 4 to $93 \%$.

Several grass species were susceptible to infection with TriMV (Table 8). These species, also reported as hosts of WSMV, included jointed goatgrass (24), wild oats (24), cheatgrass (downy brome; 20,24), field brome (20,24), prairie cupgrass (3), tapertip cupgrass (D. L. Seifers, unpub-

Table 5. Numbers of oat plants with mosaic symptoms following mechanical inoculation with Triticum mosaic virus (TriMV) or Wheat streak mosaic virus (WSMV) and enzyme-linked immunosorbent assay (ELISA) values from symptomatic (S) or nonsymptomatic (NS) plants ${ }^{\mathrm{a}}$

\begin{tabular}{|c|c|c|c|c|c|c|}
\hline \multirow[b]{3}{*}{ Plant source } & \multirow[b]{3}{*}{ TriMV $^{d}$} & \multirow[b]{3}{*}{ WSMV $^{d}$} & \multicolumn{4}{|c|}{ Antiserum (absorbance value) ${ }^{b}$} \\
\hline & & & \multicolumn{2}{|c|}{ TriMV } & \multicolumn{2}{|c|}{ WSMV } \\
\hline & & & $\mathbf{S}$ & NS & $\mathbf{S}$ & NS \\
\hline Armor & $23 / 26$ & $30 / 30$ & 0.143 & 0.009 & 1.051 & NA \\
\hline Brawn & $24 / 25$ & $14 / 25$ & 0.197 & 0.001 & 0.764 & 0.009 \\
\hline Chairman & $24 / 31$ & $27 / 29$ & 0.231 & 0.007 & 0.961 & 0.008 \\
\hline Lodi & $6 / 20$ & $23 / 24$ & 0.152 & 0.005 & 0.994 & 0.012 \\
\hline Rio Grande & $9 / 27$ & $28 / 29$ & 0.150 & 0.004 & 1.111 & 0.001 \\
\hline Tomahawk wheat & $31 / 31$ & $27 / 27$ & 0.206 & NA & 0.999 & NA \\
\hline TriMV ELISA control (EC) & NA & NA & 0.181 & NA & 0.036 & NA \\
\hline WSMV EC & NA & NA & 0.023 & NA & 0.676 & NA \\
\hline Healthy wheat EC & NA & NA & NA & 0.010 & NA & 0.021 \\
\hline
\end{tabular}

a Inoculation viruses were the 06-123 isolate of TriMV and the Sidney 81 isolate of WSMV.

${ }^{b}$ Mean absorbance values were from one experiment. Means were determined from the numbers of symptomatic or nonsymptomatic plants in a treatment (e.g., the 0.143 value for Armor oat was the mean of the ELISA values of the 23 symptomatic plants). Because only symptomatic plant extracts reacted with antibodies to the homologous virus with which the plants were inoculated and not symptomless plants, the plants in the other experiments were not analyzed by ELISA.

${ }^{c}$ Tomahawk was a wheat cultivar all other entries are oat. Temperature range was 18 to $29^{\circ} \mathrm{C}$ during the experiments.

${ }^{d}$ The numerator represents the number of systemically infected plants with mosaic symptoms and the denominator the total number of plants inoculated.

Table 6. Numbers of rye plants with mosaic symptoms following mechanical inoculation with Triticum mosaic virus (TriMV) or Wheat streak mosaic virus (WSMV) and enzyme-linked immunosorbent assay (ELISA) values from symptomatic (S) or nonsymptomatic (NS) plants ${ }^{\mathrm{a}}$

\begin{tabular}{|c|c|c|c|c|c|c|}
\hline \multirow[b]{3}{*}{ Plant source ${ }^{c}$} & \multirow[b]{3}{*}{ TriMV $^{d}$} & \multirow[b]{3}{*}{ WSMV $^{d}$} & \multicolumn{4}{|c|}{ Antiserum (absorbance value) $^{\mathbf{b}}$} \\
\hline & & & \multicolumn{2}{|c|}{ TriMV } & \multicolumn{2}{|c|}{ WSMV } \\
\hline & & & $\mathbf{S}$ & NS & $\mathbf{S}$ & NS \\
\hline Bonel & $19 / 25$ & $9 / 25$ & 0.225 & 0.001 & 0.658 & NA \\
\hline Mayton & $15 / 29$ & $6 / 29$ & 0.313 & 0.013 & 0.408 & 0.012 \\
\hline Tomahawk wheat & $32 / 32$ & $34 / 34$ & 0.455 & NA & 1.129 & NA \\
\hline TriMV ELISA control (EC) & NA & NA & 0.217 & NA & 0.032 & NA \\
\hline WSMV EC & NA & NA & 0.006 & NA & 1.263 & NA \\
\hline Healthy wheat EC & NA & NA & NA & 0.015 & NA & 0.023 \\
\hline
\end{tabular}

${ }^{a}$ Inoculation viruses were the 06-123 isolate of TriMV and the Sidney 81 isolate of WSMV.

${ }^{\mathrm{b}}$ Mean absorbance values are from the one experiment. Means were determined from the numbers of symptomatic or nonsymptomatic plants in a treatment (e.g., the 0.225 value for Bonel rye was the mean of the ELISA values of the 19 symptomatic plants). Because only symptomatic plant extracts reacted with antibodies to the homologous virus with which the plants were inoculated and not symptomless plants, the plants in the other experiments were not analyzed by ELISA.

${ }^{c}$ Tomahawk was a wheat cultivar and all other entries were rye. Temperature range was 18 to $30^{\circ} \mathrm{C}$ during the experiments.

$\mathrm{d}$ The numerator represents the number of systemically infected plants with mosaic symptoms and the denominator the total number of plants inoculated. 
Table 7. Numbers of triticale plants with mosaic symptoms following mechanical inoculation with Triticum mosaic virus (TriMV) or Wheat streak mosaic virus (WSMV) and enzyme-linked immunosorbent assay (ELISA) values from symptomatic (S) or nonsymptomatic (NS) plants ${ }^{\mathrm{a}}$

\begin{tabular}{|c|c|c|c|c|c|c|}
\hline \multirow[b]{3}{*}{ Plant source ${ }^{c}$} & \multirow[b]{3}{*}{ TriMVd } & \multirow[b]{3}{*}{ WSMV $^{d}$} & \multicolumn{4}{|c|}{ Antiserum (absorbance value) } \\
\hline & & & \multicolumn{2}{|c|}{ TriMV } & \multicolumn{2}{|c|}{ WSMV } \\
\hline & & & $\mathbf{S}$ & NS & $\mathbf{S}$ & NS \\
\hline ARCIA & $26 / 26$ & $0 / 34$ & 0.373 & NA & NA & 0.004 \\
\hline FL010-G7 & $26 / 36$ & $5 / 27$ & 0.307 & 0.008 & 0.166 & 0.010 \\
\hline FL98122-H3 & $37 / 38$ & $33 / 33$ & 0.293 & 0.015 & 0.537 & NA \\
\hline FL98178-H4 & $26 / 31$ & $0 / 35$ & 0.328 & 0.030 & NA & 0.024 \\
\hline NCPT01-1433 & $25 / 25$ & $0 / 32$ & 0.417 & NA & NA & 0.034 \\
\hline NCPT04-2151 & $17 / 23$ & $7 / 23$ & 0.307 & 0.012 & 0.412 & 0.012 \\
\hline NCT021619 & $29 / 29$ & $15 / 23$ & 0.238 & NA & 0.552 & 0.017 \\
\hline NCT99-821 & $19 / 19$ & $4 / 17$ & 0.177 & NA & 0.349 & 0.012 \\
\hline NE03T407 & $21 / 25$ & $15 / 29$ & 0.572 & 0.007 & 0.402 & 0.006 \\
\hline NE03T449 & $23 / 24$ & $16 / 23$ & 0.467 & 0. & 0.487 & 0.017 \\
\hline NT01435 & $29 / 29$ & $26 / 29$ & 0.466 & NA & 0.583 & 0.027 \\
\hline NT01451 & $27 / 27$ & $12 / 30$ & 0.686 & NA & 0.455 & 0.011 \\
\hline NT02458 & $22 / 22$ & $21 / 21$ & 0.403 & NA & 0.521 & NA \\
\hline Sunland & $32 / 32$ & $3 / 36$ & 0.504 & NA & 0.282 & 0.015 \\
\hline Trical 342 & $28 / 28$ & $28 / 28$ & 0.392 & NA & 0.459 & NA \\
\hline Tomahawk wheat & $37 / 37$ & $34 / 34$ & 0.267 & NA & 0.463 & NA \\
\hline TriMV ELISA control (EC) & NA & NA & 1.404 & NA & 0.068 & NA \\
\hline WSMV EC & NA & NA & 0.041 & NA & 1.149 & NA \\
\hline Healthy wheat EC & NA & NA & NA & 0.017 & NA & 0.053 \\
\hline
\end{tabular}

a Inoculation viruses were the 06-123 isolate of TriMV and the Sidney 81 isolate of WSMV.

b Mean absorbance values are from one experiment. Means were determined from the numbers of symptomatic or nonsymptomatic plants in a treatment (e.g., the 0.373 value for Arcia triticale was the mean of the ELISA values of the 26 symptomatic plants). Because only symptomatic plant extracts reacted with antibodies to the homologous virus with which the plants were inoculated and not symptomless plants, the plants in the other experiments were not analyzed by ELISA.

c Tomahawk was a wheat cultivar and all other entries were triticale. Temperature range was 16 to $31^{\circ} \mathrm{C}$ during the experiments.

$\mathrm{d}$ The numerator represents the number of systemically infected plants with mosaic symptoms and the denominator, the total number of plants inoculated. Plants were from two experiments.

lished), and green bristlegrass $(3,4,20,24)$. There were also many of the grasses we tested that were not hosts for TriMV but have been reported as hosts of WSMV (Table 8). These species that are not susceptible to infection with WSMV included barnyardgrass $(3,20,24)$, pearl millet $(11)$, mat sandbur $(3,4,20,24)$, hairy crabgrass (24), stinkgrass $(4,20)$, fall panicgrass (20), broomcorn millet (19), and the sorghum lines IS1056, KS56A, PI550610, TX626, TX632, TX636, and TX2567 (11). The sorghum lines tested may not be ideal hosts to separate WSMV from TriMV because not all WSMV isolates will infect these sorghum lines (11). In the current study, pearl millet plants were not susceptible to infection with TriMV but this species has been reported as a host of WSMV (11). However, it has been demonstrated that not all WSMV isolates can infect pearl millet (11).

We showed that many grasses are not hosts for TriMV (Table 8). These grasses that are not hosts of WSMV include blue grama $(24,26)$, big bluestem (20), little bluestem (20), eastern gamagrass (20), johnsongrass, $(19,20,24)$, orchardgrass $(18,19,24)$, perennial ryegrass (23), switchgrass $(19,20,24)$, quackgrass $(17,20,24)$, sideoats grama (24), intermediate wheatgrass $(7,18,20)$, tall wheatgrass $(20,24)$, western wheatgrass $(19,20,24)$, yellow foxtail $(13,20,24)$, and possibly Australian windmill grass and rhodes grass, but no information is available if they are susceptible to WSMV infection.
In summary, we have identified an experimental host range using mechanical inoculation with the 06-123 isolate of TriMV and the Sidney 81 isolate of WSMV. We have shown that maize in combination with barley and triticale accessions can be used to separate WSMV and TriMV in plants infected by both viruses. Because these species are easy to grow, they would be the desired species to use for this purpose. We also showed that several grass species were susceptible to TriMV and not WSMV but, due to their slow growth habits, they would be less desirable for use as differential hosts. In addition, we showed that many grasses were not susceptible to infection with TriMV, and these grasses are also reported not to be hosts of WSMV. Additional work of importance would be analysis of these differential hosts using a large set of TriMV isolates from a wide geographic region.

\section{ACKNOWLEDGMENTS}

We thank J. Ackerman for his excellent technical assistance in planting and inoculating, and in analysis of such plant material by ELISA during these studies.

\section{LITERATURE CITED}

1. Bottacin, A., and Nassuth, A. 1990. Evaluation of Ontario-grown cereals for susceptibility to wheat streak mosaic virus. Can. J. Plant Sci. 12:267-272.

2. Burrows, M. Franc, G., Rush, C., Blunt, T., Ito, D., Kinzer, K., Olson, J., O’Mara, J., Price, J., Tande, C., Ziems, A., and Stack, J. 2009. Occurrence of viruses in wheat in the Great Plains region, 2008. Plant Health Progress doi:10.1094/PHP-2009-0706-01-RS.
3. Christian, M. L., and Willis, W. G. 1993 Survival of wheat streak mosaic virus in grass hosts in Kansas from what harvest to fall wheat emergence. Plant Dis. 77:239-242.

4. Connin, R. V. 1956. The host range of the wheat curl mite, vector of wheat streak mosaic. J. Econ. Entomol. 48:1-4.

5. Fellers, J. P. Seifers, D, Ryba-White, M., and Martin, T. J. 2009. The complete sequence of Triticum mosaic virus, a new wheat-infecting virus of the High Plains. Arch. Virol. 154:1511-1515.

6. Gardner, W. S., Wells, D. G., and Lay, C. L. 1969. Resistance to wheat streak mosaic virus in triticale as determined by blast inoculation. (Abstr.) Phytopathology 59:1027.

7. McKinney, H. H., and Sando, W. J. 1951 Susceptibility and resistance to the wheat streak mosaic virus in the genera Triticum, $\mathrm{Ag}$ ropyron, Secale, and certain hybrids. Plant Dis. Rep. 35:476-479.

8. McMullen, M. D., and Louie, R. 1991. Identification of a gene for resistance to wheat streak mosaic virus in maize. Phytopathology 81:624-627.

9. Niblett, C. L., Newman, M. A., Livers, R. W., and Young, J. R. 1976. Strains of wheat streak mosaic virus. Ann. Wheat Newsl. 6:85-86.

10. Seifers, D. L. 1992. Partial characterization of a Colorado isolate of Agropyron mosaic virus. Plant Dis. 76:564-569.

11. Seifers, D. L., Harvey, T. L., Kofoid, K. D., and Stegmeier, W. D. 1996. Natural infection of pearl millet and sorghum by wheat streak mosaic virus in Kansas. Plant Dis. 80:179-185.

12. Seifers, D. L., Harvey, T. L., Martin, T. J., and Jensen, S. G. 1997. Identification of the wheat curl mite as the vector of the High Plains virus of corn and wheat. Plant Dis. 81:1161-1166.

13. Seifers, D. L., Harvey, T. L., Martin, T. J., and Jensen, S. G. 1998. A partial host range of the High Plains virus of corn and wheat. Plant Dis. 82:875-879.

14. Seifers, D. L., and Martin, T. J. 1988. Correlation of low level Wheat streak mosaic virus re- 
Table 8. Numbers of plants with mosaic symptoms following mechanical inoculation with Triticum mosaic virus (TriMV)

\begin{tabular}{|c|c|c|c|}
\hline Plant species & Common name or variety & $\mathbf{N S P}^{\mathbf{a}}$ & Host for WSMV ${ }^{b}$ \\
\hline Aegilops cylindrica & Jointed goatgrass & $42 / 52$ & S $(20,24)$ \\
\hline Andropogon gerardii & Big bluestem & $0 / 48$ & I (20) \\
\hline Avena fatua & Wild oat & $29 / 66$ & $\mathrm{~S}(24)$ \\
\hline Bouteloua curtipendula & Sideoats grama & $0 / 39$ & I (24) \\
\hline B. gracilis & Blue grama 'El Reno' & $0 / 19$ & I (26) \\
\hline Bromus arvenis & Field brome & $24 / 49$ & $\mathrm{~S}(20,24)$ \\
\hline B. inermus & Smooth brome & $0 / 34$ & $\mathrm{I}(18,19)$ \\
\hline B. secalinus & Rye brome & $5 / 8$ & $S(20,24)$ \\
\hline B. tectorum & Cheatgrass & $15 / 22$ & $S(20,24)$ \\
\hline Cenchrus longispinus & Mat sandbur & $0 / 18$ & $\mathrm{~S}(3,4,20,24)$ \\
\hline Chloris gayana & Rhodes grass & $0 / 34$ & No information \\
\hline C. ventricosa & Australian windmill grass & $0 / 46$ & No information \\
\hline Dactylis glomerata & Orchardgrass & $0 / 17$ & I $(18,19,24)$ \\
\hline Digitaria sanguinalis & Hairy crabgrass & $0 / 63$ & S (24) \\
\hline Echinochloa crusgalli & Barnyardgrass & $0 / 27$ & $\mathrm{~S}(3,20,24)$ \\
\hline Elymus repens & Quackgrass & $0 / 60$ & I $(7,10,20,24)$ \\
\hline Eragrostis cilianensis & Stinkgrass & $0 / 47$ & $\mathrm{~S}(4,20)$ \\
\hline Eriochloa acuminata & Tapertip cupgrass & $4 / 20$ & S (D. L. Seifers, unpublished) \\
\hline E. contracta & Prairie cupgrass & $2 / 20$ & $\mathrm{~S}(3)$ \\
\hline Lolium perenne ssp. perenne & Perennial ryegrass & $0 / 43$ & I (23) \\
\hline Panicum dichotomiflorum & Fall panicgrass & $0 / 51$ & S (20) \\
\hline P. miliaceum & Broomcorn millet & $0 / 61$ & S (19) \\
\hline$P$. virgatum & Switchgrass & $0 / 32$ & I $(19,20,24)$ \\
\hline Pascopyrum smithii & Western wheatgrass & $0 / 14$ & I $(19,20,24)$ \\
\hline Pennisetum glaucum & Pearl millet & $0 / 67$ & $\mathrm{~S}(11)$ \\
\hline Poa pratensis & Kentucky bluegrass 'Glade' & $0 / 58$ & I $(20,24)$ \\
\hline Schizachyrium scorparium & Little bluestem & $0 / 29$ & I (20) \\
\hline Setaria glauca & Yellow foxtail & $0 / 53$ & I $(20,24)$ \\
\hline S. viridis & Green bristlegrass & $4 / 25$ & $\mathrm{~S}(3,4,20,24)$ \\
\hline Sorghum bicolor & IS 1056 & $0 / 30$ & $\mathrm{~S}(11)$ \\
\hline S. bicolor & KS56A & $0 / 30$ & $\mathrm{~S}(11)$ \\
\hline S. bicolor & PI 550610 & $0 / 53$ & $\mathrm{~S}(11)$ \\
\hline S. bicolor & TX 626 & $0 / 18$ & $\mathrm{~S}(11)$ \\
\hline S. bicolor & TX 632 & $0 / 42$ & $\mathrm{~S}(11)$ \\
\hline S. bicolor & TX 636 & $0 / 43$ & $\mathrm{~S}(11)$ \\
\hline S. bicolor & TX 2567 & 0/39 & $\mathrm{S}(11)$ \\
\hline S. halepense & Johnsongrass & $0 / 37$ & I $(19,20,24)$ \\
\hline Thinopyrum intermedium & Intermediate wheatgrass & $0 / 80$ & I $(19,20,24)$ \\
\hline T. ponticum & Tall wheatgrass & $0 / 54$ & $\mathrm{I}(20,24)$ \\
\hline Tripsacum dactyloides & Eastern gamagrass & $0 / 16$ & I $(24)$ \\
\hline
\end{tabular}

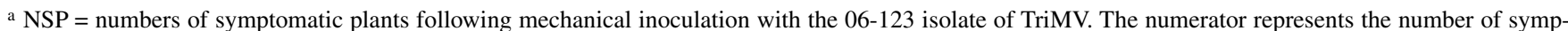
tomatic plants and the denominator the total number of plants mechanically inoculated. Experiments were repeated two times for species developing symptoms and three times for species that remained symptomless following inoculation.

${ }^{\mathrm{b}}$ Susceptible (S) or immune (I) rating of a plant species is followed by the reference number in parentheses that established that response to inoculation with Wheat streak mosaic virus (WSMV).

sistance in Triumph 64 wheat with low virus titer. Phytopathology 78:703-707.

15. Seifers, D. L., Martin, T. J., Harvey, T. L., Fellers, J. P., and Michaud, J. P. 2009. Identification of the wheat curl mite as the vector of Triticum mosaic virus. Plant Dis. 93:25-29.

16. Seifers, D. L., Martin, T. J., Harvey, T. L., Fellers, J. P., Stack, J. P., Ryba-White, M., Haber, S., Krokhin, O., Spicer, V., Lovat, N., Yamchuk, A., and Standing, K. G. 2008. Triticum mosaic virus: a new virus isolated from wheat in Kansas. Plant Dis. 92:808-817.

17. Seifers, D. L., Martin, T. J., Harvey, T. L., and Gill, B. S. 1995. Temperature sensitivity and efficacy of wheat streak mosaic virus resistance derived from Agropyron intermedium. Plant Dis. 79:1104-1106.

18. Shannon, E. L., and Bridgmon, G. H. 1962.
Strains and varieties of grass species resistant to western wheat streak mosaic virus. (Abstr.) Phytopathology 52:364.

19. Sill, W. H., Jr., and Agusiobo, P. C. 1955. Host range studies of the wheat streak mosaic virus. Trans. Kans. Acad. Sci. 56:411-417.

20. Sill, W. H., Jr., and Connin, R. V. 1953. Summary of the known host range of wheat streak mosaic virus. Trans. Kans. Acad. Sci. 56:411417.

21. Sill, W. H., Jr., and del Rosario, M. S. 1959. Transmission of wheat streak mosaic virus to corn by the Eriophyid mite, Aceria tulipae. Phytopathology 49:396.

22. Slykhuis, J. T. 1955. Aceria tulipae Keifer (Acarina:Eriophyidae) in relation to the spread of wheat streak mosaic. Phytopathology 45:116-128.
23. Slykhuis, J. T., and Bell, W. 1966. Differentiation of Agropyron mosaic, Wheat streak mosaic, and a hitherto unrecognized Hordeum mosaic virus in Canada. Can. J. Bot. 44:1191 1208

24. Somensen, H. W., and Sill, W. H., Jr. 1970. The wheat curl mite, Aceria tulipae Keifer, in relation to epidemiology and control of wheat streak mosaic. Kans. State Univ. Agric. Exp. Stn. Res. Publ. 162.

25. Tatineni, S., Ziems, A. D., Wegulo, S. N., and French, R. 2009. Triticum mosaic virus: a distinct member of the family Potviridae with an unusually long leader sequence. Phytopathology 99:943-950.

26. Unknown. 1989. Wheat streak mosaic. In: Report on Plant Disease No. 120. University of Illinois Extension, Urbana. 